\title{
PENDIDIKAN ISLAM DI ERA GLOBALISASI: Antara Konsepsi dan Aplikasi
}

\author{
Syaripudin Basyar \\ Fakultas Tarbiyah dan Keguruan UIN Raden Intan Lampung \\ syaripudin@ radenintan.ac.id
}

\begin{abstract}
Abstrak
Penelitian ini akan memaparkan "Pendidikan Islam di Era Globalisasi: Antara Konsepsi dan Aplikasi" yang diawali permasalahan fital mengapa pendidikan Islam di Era Globalisasi niscaya dikaji secara konsepsi dan aplikasi? dengan tujuan penelitian mengekspolasi keniscayaan pendidikan Islam di Era Globalisasi dikaji secara Konsepsi dan Aplikasi. Sedangkan penelitian ini dapat memberikan kontribusi teoritis dan kontribusi praktis. Dimana kontribusi teoritis dapat dijadikan paradigma baru bagi peneliti berikutnya untuk melakukan studi tentang pendidikan Islam di Era Globalisasi: Antara Konsepsi dan Aplikasi. Sementara kontribusi praktis, bahwa pendidikan Islam sangat relevan dan representatif untuk direalisasikan secara konsepsi dan aplikasi di era globalisasi saat ini, dimana disiplin ilmu ini selalu muttakhir, aktual, berkembang serta update pada setiap era dan generasi. Selanjutnya, penelitian ini merupakan studi kepustakaan (library research) dengan cara menela'ah berbagai literatur terkait dengan "Pendidikan Islam di Era Globalisasi: Antara Konsepsi dan Aplikasi", secara prioritas literatur yang ditulis oleh para pakar pendidikan Islam klasik dan kontemporer. Sedangkan metode yang akan digunakan dalam penelitian ini adalah deskriptif dan analisis. Sementara prosedur pengolahan data, digunakan Content Analysis. Mencermati paparan di atas, maka temuan penelitian yang diharapkan adalah "Desain Pendidikan Islam di Era Globalisasi", dimulai dari desain tujuan pendidikan Islam, desain kurikulum pendidikan Islam, dan desain lembaga pendidikan Islam.
\end{abstract}

Kata Kunci: Pendidikan Islam, Era Globalisasi, Konsepsi dan Aplikasi 


\section{PENDAHULUAN}

Pendidikan Islam saat ini, dihadapkan pada berbagai perkembangan yang meniscayakan untuk melakukan perubahan dan perbaikan sehingga mampu melakukan penyesuaian terhadap perubahan tersebut. Perkembangan ilmu pengetahuan dan teknologi (iptek) menjadi tantangan bagi pendidikan Islam, ${ }^{1}$ terutama dalam menghadapi era globalisasi yang telah mampu mengsis-tematisasikan jarak dan waktu antar berbagai negara dalam pertukaran informasi dan pengetahuan, khususnya dalam bidang pendidikan Islam. Perkembangan ilmu pengetahuan dan teknologi itu, telah melahirkan aneka media yang dapat difungsikan untuk mengembangkan pendidikan Islam dimaksud. Jika pada era klasik, pendidikan Islam hanya dapat menjangkau sasaran masyarakat lokal dengan kualitas yang relatif rendah, dengan adanya multi media, terutama internet, maka pendidikan Islam bisa berlangsung dengan jangkauan tanpa batas, waktu yang sangat singkat, dan kualitas yang lebih tinggi. Para pakar pendidikan Islam dituntut untuk menggunakan dan mengembangkan media pendidikan terupdate sehingga pendidikan Islam dapat bersanding dengan pendidikan umum yang akhirakhir ini mengalami lompatan signifikan yang sangat meng-gembirakan. Hal ini akan terjadi, jika para pimpinan dan pendidik di berbagai lembaga pendidikan Islam memulai untuk meningkatkan kualitas pendidikan dan kinerjanya. Jika tidak, maka citacita meningkatkan kualitas pendidikan Islam hanyalah sebuah impian belaka.

Sementara konsep pendidikan dalam Islam adalah "long life education" atau dalam bahasa Hadits Rasul "sejak dari pangkuan ibu

${ }^{1}$ Terminologi pendidikan dalam konteks Islam pada umumnya mengacu kepada term al-tarbiyah, al-ta'dib, dan al-ta'lim. Dari ketiga istilah tersebut term yang popular digunakan dalam praktik pendidikan Islam adalah term al-tarbiyah. Sedangkan term al-ta'dib dan alta'lim jarang sekali digunakan. Padahal kedua terminologi dimaksud telah digunakan sejak awal pertumbuhan pendidikan Islam. (Omar Mohammad al-Thoumy al-Syaibany dalam alRasyidin dan Samsul Nizar, Fislsafat Pendidikan Islam: Pendekatan Historis, Teoritis dan Praktis, Jakarta: Ciputat Press, 2005, Cet.ke-2). Meskipun dalam kondisi tertentu, ketiga terma tersebut memiliki kesamaan makna. Namun secara substansial, setiap term memiliki perbedaan, baik secara tekstual maupun kontekstual. Untuk itu, perlu diekspresikan paparan dan analisis terhadap ketiga term pendidikan Islam itu dengan beberapa argumentasi logis dari beberapa pemikiran para pakar pendidikan Islam.

${ }^{2}$ Long Life Education (konsep pendidikan seumur hidup) adalah rancangan atau gagasan tentang proses pembimbingan manusia yang terus berlangsung selama ia hidup. Konsep pendidikan seumur hidup yang disebutkan di atas, sejalan dengan salah satu adegium masyhür yang sering dikemukakan para ahli hikmahyakni; أطلبوا العلم من المهد إلى اللحد tuntutlah ilmu mulai dari ayunan sampai ke liang lahat). Dari konsep inilah, lahir beberapa istilah yang mengacu pada termininologi pendidikan seumur hidup, yakni dalam International Dictionary of Education dikatakan bahwa pendidikan seumur tiada lain kecuali adalah pendidikan orang dewasa (adult education), pendidikan permanen (educational permanent) atau pendidikan berulang (recurrent education). Istilah tersebut, kemudian terkonsep secara 
sampai ke liang lahat" (from the cradle to the grave). Term ini memiliki pengertian bahwa pada tahap awal, khususnya sebelum memasuki bangku sekolah, peran orang tua---terutama ibu---amatlah krusial dan menentukan, mengingat pada usia balita inilah orang tua, memegang peran penting di dalam menanamkan nilai-nilai keislaman kepada anak. Sayangnya orang tua bukanlah satu-satunya pendidik di rumah, ada pendidik lain yang kadangkadang peranannya justru lebih dominan dari orang tua yang di Barat disebut dengan idiot box atau televisi. Dampak lebih jauh televisi terhadap perkembangan anak balita seperti yang dikatakan Hiesberger (1981) bisa mengarah pada " $a$ dominant voice in our lives dan a major agent of socialization in the lives of our children" (menjadi suara dominan dalam kehidupan kita dan agen utama proses sosialisasi dalam kehidupan anak-anak kita). Tentu saja peran orang tua tidak berhenti sampai di sini, keterlibatan orang tua juga diperlukan pada fase-fase berikutnya saat anak mulai memasuki usia sekolah, baik level dasar, maupun level menengah. Bahkan menjelang masa pubertas---yakni pada usia antara dua belas sampai delapan belas tahun---anak menjalani episode yang sangat kritis di mana sukses atau gagalnya karir masa depan anak sangat tergantung pada periode ini. Robert Havinghurst, pakar psikolog Amerika, menyebutkan periode ini sebagai "developmental task"3 atau proses perkembangn anak menuju usia dewasa.

redaksional dalam istilah long life education atau long life integrated education. Dengan konsep pendidikan seumur hidup, berarti manusia mengalami proses pendidikan secara berkesinambungan, atau secara terus menenerus dan kontinyu, serta berlangsung sampai ajalnya tiba. Redja Mudyahardjo menjelasakan bahwa hidup (life) mempunyai tiga komponen yang saling berhubungan satu dengan lainnya, yaitu individu; masyarakat; dan lingkungan fisik. Perjalanan manusia seumur hidup (lifelong) mengandung perkembangan dan perubahan yang juga mencakup tiga komponen yakni: perkembangan individu, meliputi; masa balita, masa kanak-kanak, masa sekolah, masa remaja, dan masa remaja; Aspek-aspek perkembangan kepribadian, meliputi; fisik, mental, sosial, dan emosional; dan Landasan konsep pendidikan yang terbangun dari tiga komponen, yaitu; landasan pendidikan; isi pendidikan, dan tata cara pendidikan. (Redja Mudyahardjo, Filsafat Ilmu Pendidikan, Bandung: Remaja Rosdakarya, 2004, Cet.ke-3).

${ }^{3} \mathrm{~A}$ developmental task is one that arises predictably and consistently at or about a certain period in the life of the individual (Havighurst, 1948, 1953). The concept of developmental tasks assumes that human development in modern societies is characterized by a long series of tasks that individuals have to learn throughout their lives. Some of these tasks are located in childhood and adolescence, whereas others arise during adulthood and old age (see also Heckhausen, 1999). Successful achievement of a certain task is expected to lead to happiness and to success with later tasks, while failure may result in unhappiness in the individual, disapproval by the society, and difficulty with later tasks. Developmental tasks arise from three different sources (Havighurst, 1948, 1953). First, some are mainly based on physical maturation (e.g., learning to walk). Another source of developmental tasks relates to sociostructural and cultural forces. Such influences are based on, for instance, laws (e.g., minimum age for marriage) and culturally shared expectations of development (e.g., age norms; Neugarten, Moore, and Lowe, 1965), determining the age range in which specific 
Lebih jauh ditegaskan bahwa periode developmental task ini jika dikaitkan dengan aspek budaya kehidupan anak-anak Muslim, khususnya mereka yang tinggal di negara-negara non-Muslim atau di negara Islam tapi di kota-kota besar, dapat dibayangkan situasi yang mereka hadapi. Mereka tidak pernah atau jarang melihat sikap positif terhadap Islam, baik dalam keluarga, di sekolah maupun di masyarakat. Dalam situasi seperti ini tentu merupakan tanggung jawab orang tua untuk menanamkan nilai-nilai moral, berbagai pengalaman kehidupan Islami yang pada gilirannya nanti akan mengarah pada internalisasi misi al-Qur'an dan al-Sunnah. Peran orang tua seperti ini akan sangat membantu anak dalam memasuki kehidupan yang fungsional sebagai Muslim yang dewasa dan sebagai anggota yang aktif dalam komunitas Islam. Apabila anak menampakkan tanda-tanda sikap yang negatif terhadap Islam yang disebabkan oleh pengaruh dari sekolah, masyarakat atau karena kecerobohan dan kelengahan orang tua, maka hal ini akan mengakibatkan penolakan anak terhadap hidup Islami dan akan gagal berintegrasi dengan komunitas Islam.

Oleh karena itu adalah tugas orang tua---khususnya dan utamanya--untuk mengatur strategi yang tepat dalam rangka membantu proses pembentukan pribadi anak secara spesifik dalam periode developmental task tersebut. Dalam konteks ini, orang tua niscaya memiliki wawasan pengetahuan yang luas serta dasar pengetahuan agama yang mencukupi untuk menghindari kesalahan strategi dalam mendidik anak. Di sisi lain, orang tua mengalokasikan waktu yang cukup untuk memberikan kesempatan bagi anak berinteraksi serta meresapi sikap-sikap Islami dalam perilaku kesehariannya. Persoalannya adalah secara faktual tidak semua orang tua memiliki wawasan pengetahuan yang mumpuni, khususnya dalam bidang pedagogik ${ }^{4}$ anak dan nilai-nilai dasar Islami. Dalam situasi semacam ini

developmental tasks have to be mastered. The third source of developmental tasks involves personal values and aspirations. These personal factors result from the interaction between ontogenetic and environmental factors, and play an active role in the emergence of specific developmental tasks (e.g., choosing a certain occupational pathway). (Encyclopedia.com).

${ }^{4}$ pedagogy is the discipline that deals with the theory and practice of education; it thus concerns the study of how best to teach. spanning a broad range of practice, its aims range from furthering liberal education (the general development of human potential) to the narrower specifics of vocational education (the imparting and acquisition of specific skills). instructive strategies are governed by the pupil's background knowledge and experience, situation, and environment, as well as learning goals set by the student and teacher. one example would be the socratic schools of thought. johann friedrich herbart (4 may 1776-14 august 1841) is the founding father of the conceptualization of pedagogy, or, the theory of education. herbart's educational philosophy and pedagogy highlighted the correlation between personal development and the resulting benefits to society. in other words, herbart proposed that humans become fulfilled once they establish themselves as productive citizens. herbartianism refers to the movement underpinned by herbart's theoretical perspectives. referring to the teaching process, herbart suggested 5 steps as crucial components. 
orang tua perlu mengambil langkah-langkah konkrit sebagai upaya mengantar anaknya menuju pintu gerbang masa depan yang cerah, sehat dan agamis dalam konteks pendidikan Islam di era globalisasi ini.

Sedangkan globalisasi dalam pengertian umum dapat dipahami sebagai dominasi aneka usaha besar dan raksasa atas tataniaga dan sistem keuangan internasional yang kita ikuti. Ia juga dipahami sebagai pembentukan selera warga masyarakat secara global/mendunia yang juga turut kita nikmati saat ini. Deretan penjualan "makanan siap telan" (fast food) menjadi saksi akan pemaknaan seperti itu. Selera kita ditentukan oleh pasar, bukannya menentukan pasar. Dari fakta ini saja sudah cukup untuk menjadi bukti akan kuatnya dominasi tersebut. Pengertian lain globalisasi adalah dominasi komersial dan pengawasan atas sistem finansial dalam hubungan antar negara, inilah yang sekarang menentukan sekali tata hubungan antara negaranegara yang ada. Berdasarkan term ini, dapat dipahami bahwa fenomena globalisasi juga memberikan banyak ancaman bagi kehidupan manusia, dalam konteks Indonesia misalnya, beberapa ancaman globalisasi adalah semakin tidak tertahannya ekspansi kapital, ekspansi investasi, proses produksi dan pemasaran global. ${ }^{5}$ Ancaman inilah yang nantinya akan berpengaruh secara langsung---sebab melalui penentuan kebijakan pemerintahan---bagi proses peminggiran kaum tertindas-terpinggir, semacam: buruh/karyawan, petani, kaum pinggiran kota, guru, pelajar, mahasiswa/pendidikan, masyarakat lokal. Betapa tidak, saat ini tampak jelas dihadapan kita, bahwa beberapa kebutuhan "primer" rakyat telah disunat

specifically, these 5 steps include: preparation, presentation, association, generalization, and application. herbart suggests that pedagogy relates to having assumptions as an educator and a specific set of abilities with a deliberate end goal in mind. (wikipedia.org).

${ }^{5}$ Pemasaran Global adalah pemasaran berkala seluas dunia. Peluang pasar selalu terbuka bagi semua pelaku usaha, tak terkecuali di pasar ekspor. Yang penting mesti kreatif dan mau berinovasi dalam mengembangkan pasar.Pelaku bisnis yang tangguh tentu tak mudah ditenggelamkan oleh setiap perubahan tantangan bisnis meski tantangan yang datang semakin berat. Bagi para pebisnis sejati, kesulitan justru menjadi cambuk yang melecut semangat untuk memecahkannya sehingga usaha dapat semakin berkembang dan maju. Karakter semacam itu tampaknya juga melekat pada sederet pengelola perusahaan di Indonesia yang juga terlihat dari kinerja perusahaan yang dikelola yang hasilnya memang super. Di samping, didukung oleh Manajemen Pemasaran Global, yaitu disiplin ilmu universal dapat diterapkan di mana saja, baik di Amerika atau di Jepang.Kebiasaan pemasaran bervariasi dari satu negara ke negara lain. Konsep Pemasaran : Sekitar tahun 1960 konsep pemasaran strategis, dengan konteks lingkungan eksternal yang lebih luas spt pelanggan, persaingan, kebijakan dan peraturan pemerintah, ekonomi secara luas, dan tekanan ekonomi makro yang membentuk evolusi pasar. Selain itu tujuan pemasaran yang berubah secara drastis, dari laba ke keuntungan bagi pemercaya (stakeholder) Tiga Prinsip Pemasaran1. Nilai Pelanggan dan Persamaan Nilai2. Keunggulan Kompetitif atau Diferensial3. Fokus Pentingnya Pemasaran Global Pemasaran global adalah proses memfokuskan sumber daya dan sasaran dari sebuah perusahaan terhadap peluang pemasaran global. (Wikipedia.org) 
dengan ditiadakan ataupun dikuranginya subsidi; padahal yang kita tahu bahwa kehidupan yang layak, pekerjaan, kekayaan alam, pendidikan adalah kewajiban negara untuk melaksanakannya sebagaimana terdapat dalam undang-undang dasar dan falsafah pancasila.

Mencermati paparan di atas, maka ada tiga permasalahan fital yang menjadikan peneliti tertarik untuk membahas disiplin ilmu ini, pertama: pendidikan Islam selalu update untuk dikaji baik pendidikan Islam era klasik maupun era modern; kedua: pendidikan Islam di era globalisasi sangat menarik untuk dieksplorasi dari sisi kajian konsepsi dan kajian aplikasi; ketiga: pendidikan Islam di era globalisasi sangat rentan dengan tantangan dan peluang, sehingga dapat memunculkan beragam temuan sebagai kontribusi postif bagi seluruh umat manusia. Ketiga permasalahan substansial inilah merupakan urgensitas penelitian ini ditampilkan. Untuk mempertajam ketiga persoalan tersebut, maka akan disajikan beberapa kajian terdahulu yang relevan sebagai bahan komparasi penelitian ini. Beberapa kajian terdahulu dimaksud dapat dicermati berikut ini.

Mulyawan S. Nugraha (2009) telah menulis karya ilmiah tentang "Islam dan Tantangan Globalisasi: Berbagai Paradigma Islam dalam Menghadapi Globalisasi" dengan simpulan bahwa masyarakat Islam, khususnya di Indonesia saat ini secara faktual telah berkembang dua paradigma kontradiktif di dalam menghadapi berbagai tantangan globalisasi, paradigma pertama cenderung sangat konservatif sementara paradigma kedua cenderung liberal. Untuk itu penulis menawarkan perlunya kecenderungan alternatif yaitu kecenderungan yang mencoba mengintegrasikan dua kecenderungan di atas yang penulis istilahkan dengan paradigma moderat. Namun untuk merealisasikan bentuk paradigma alternatif tersebut, bukanlah persoalan mudah, tetapi memerlukan banyak upaya guna mengaktualisasikan ide tersebut. Sebagai paradigma yang mengampanyekan dimensi kelenturan, kesantunan, dan keadaban Islam. Maka paradigma ini berupaya menjadikan nilai ajaran Islam sebagai ajaran penebar kasih, cinta dan sayang (rahmatan li al-'alamien) harus menjadi paradigma yang mengakar di tengah masyarakat. Hal ini penting guna meminimalisir pandangan keagamaan yang selalu berwajah sangar dan keras yang digunakan secara sistematis oleh beberapa kalangan Muslim. Persamaan kajian terdahulu dengan kajian yang sedang berlangsung adalah sama-sama membahas pendidikan Islam di era globalisasi, sementara perbedaan yang tampak adalah kajian terdahulu mengkaji paradigma pendidikan Islam di era globalisasi, sedangkan kajian saat ini akan memaparkan konsepsi dan aplikasi pendidikan Islam di era globalisasi.

Selanjutnya Moh. Ali Aziz (2014) telah menulis tentang "Tantangan Pendidikan Islam di Era Global", dengan simpulan bahwa para pakar pendidikan Islam dituntut untuk menggunakan dan mengembangkan media 
pendidikan terupdate sehingga pendidikan Islam dapat bersanding dengan pendidikan umum yang akhir-akhir ini mengalami lompatan signifikan yang sangat menggembirakan. Term ini akan terjadi, jika para pimpinan institusi dan pendidik di berbagai institusi pendidikan Islam memulai dari dirinya sendiri untuk meningkatkan kualitas pendidikan dan kinerjanya. Selanjutnya persamaan kajian terdahulu dengan kajian yang sedang berlangsung adalah sama-sama mengkaji aspek pendidikan Islam di era globalisasi, sementara perbedaan yang tampak adalah kajian terdahulu mengkaji aspek multi media dalam meningkatkan pendidikan Islam di era global. Sedangkan kajian saat ini akan menelisik aspek konsepsi dan aplikasi pendidikan Islam di era globalisasi.

Adapun Fatih Syuhud pada tahun (2015) telah telah menulis karya ilmiah tentang "Tantangan Pendidikan Islam" dengan simpulan bahwa gambaran solusi Islami terhadap tantangan pendidikan di era globalisasi, merupakan disain besar, yang oleh sebagian kalangan mungkin dianggap terlalu romantis. Kendatipun bukan berarti mustahil dilakukan dengan melihat beberapa fenomena paling mutakhir di berbagai dunia Islam, khususnya Indonesia meliputi: semakin menipisnya dikotomi antara--meminjam istilah Clifford Geertz---Islam Santri dan Islam Abangan; semakin banyaknya pakar iptek yang berlatar belakang santri; semakin tipisnya friksi (perpecahan) yang terjadi antara berbagai organisasi Islam yang disebabkan oleh semakin tajamnya visi Islam mereka dalam awal milenium ini; dan terjadinya perubahan dahsyat dalam konstelasi politik di Indonesia dari demokrasi artifisial, menuju demokrasi yang relatif dapat diharapkan. Persamaan studi terdahulu dengan studi yang sedang berlangsung adalah sama-sama membahas substansi dan tantangan pendidikan Islam di era globalisasi, sementara perbedaan yang tampak adalah studi terdahulu fokus mengkaji tantangan pendidikan Islam di era globalisasi, sedangkan studi saat ini fokus memmaparkan pendidikan Islam di era globalisasi antara konsepsi dan aplikasi.

\section{METODE PENELITIAN}

Penelitian ini disusun berdasarkan studi kepustakaan (Library Research) dengan cara menela'ah aneka literatur yang berkaitan dengan "Pendidikan Islam di Era Globalisasi: Antara Konsepsi dan Aplikasi", secara prioritas literatur yang ditulis oleh para pakar pendidikan Islam klasik dan kontemporer. Term ini dijadikan oleh peneliti sebagai sumber primer, disertakan pula sumber sekunder. Dengan demikian, penelitian dimaksud memberikan deskripsi dan eksplorasi terhadap kajian pendidikan Islam di era globalisasi dengan informasi kepustakaan yang koprehensif. Kemudian dari data tersebut dianalisis, sehingga tampak jelas fokus kajiannya. Sedangkan metode yang akan digunakan dalam penelitian ini adalah deskriptif dan 
analisis. Kedua metode ini tidak disajikan seperated, akan tetapi diaktualisasikan secara integrated Metode deskripsif dipakai, karena dalam paparannya akan memberikan ilustrasi umum tentang permasalahan yang akan tela'ah, kemudian dari data itu akan diadakan interpretasi komprehensif. Sementara metode analisis digunakan untuk melihat secara kritis aneka permasalahan yang melatar belakangi permasalahan dimaksud. Sementara prosedur pengolahan data, digunakan Content Analysis. Hal ini tentunya penulis mengadakan analisis terhadap validitas instrumen atau data yang hendak diukur, melalui proses tahapan pengolahan data sehingga data tersebut siap diinterpretasikan dan disimpulkan.

\section{DATA DAN ANALISIS DATA}

Dalam pembahasan dan analisis data ini, akan dipaparkan secara cermat tentang pendidikan Islam antara konsepsi dan aplikasi serta era globalisasi. Dimensi pertama, meliputi Pendidikan Islam antara Konsepsi dan Aplikasi. Sementara dimensi kedua, Pendidikan Islam di Era Globalisasi. Paparan detail konteks ini, dapat dicermati secara kritis berikut ini.

\section{PENDIDIKAN ISLAM ANTARA KONSEPSI DAN APLIKASI}

Kajian pendidikan Islam $^{6}$ mencakup berbagai topik yang meliputi pemikiran, institusi, aktivitas, kebijakan, sampai pada ragam teori dan praktik atau dimensi konsepsi dan aplikasi. Mengingat bahwa pendidikan Islam telah berlangsung sejak era Rasulullah SAW serta banyaknya karya tulis ulama' klasik dan eksistensi institusi yang eksis hingga saat ini, maka substansi pendidikan Islam telah layak menjadi sebuah kajian tersendiri, bahkan memiliki teori dan konsep tersendiri pula. Maksudnya, rung lingkup, konstruksi teoritis, dan aplikasi pendidikan Islam dengan terminologi lain,

\footnotetext{
${ }^{6}$ Muhammad Tholhah Hasan mengingatkan bahwa pemerintah idealnya mempunyai kepedulian yang tinggi tergadap penyelenggaraan pendidikan Islam yang berkaitan dengan peningkatan kualitas sumber daya manusia (SDM). Pejabat yang diberi kepercayaan menduduki jabatan strategis yang berhubungan dengan peningkatan kualitas sumber daya manusia niscaya bekerja keras untuk menggalang kerjasama dengan Negara-negara lain, khususnya Timur Tengah guna membantu anak-anak Indonesia dalam memperoleh beasiswa pendidikan atau mencarikan institusi pendidikan berkualitas di Negara mana pun guna mempercepat peningkatan atau pembumian visi dan misi pendidikan Islam di negeri ini, terutama dalam membentuk mentalitas kerja dan kreativitasnya dalam pengembangan ilmu pengetahuan. Selain itu, kompetensi global juga selayaknya dijadikan bahan pertimbangan dalam membangun kualitas sumber daya manusia, apalagi salah satu di antara ciri sumber daya manusia yang diharapkan oleh Negara-negara maju dan berkembang adalah sumber daya manusia yang memiliki etos kerja yang tinggi dan mempunyai kompetensi keilmuan. (Muhammad Tholhah Hasan, Dinamika Kehidupan Religius, Jakarta: Listafariska, 2004 dalam H.M. Bashori Muchsin, et.al., Pendidikan Islam Humanistik: Alternatif Pendidikan Pembebasan Anak, Bandung: Refika Aditama, 2010, Cet.ke-1, h. 17-18
} 
memenuhi syarat untuk membangun sebuah disiplin ilmu. Di sisi lain, pendidikan Islam merupakan pendidikan yang secara spesifik memiliki ciri Islami, berbeda dengan konsep pendidikan lain yang kajiannya lebih fokus pada pemberdayaan umat berdasarkan al-Qur'an al-Karim dan al-Hadits alNabawi. Artinya, kajian pendidikan Islam bukan sekedar menyangkut aspek normatif ajaran Islam, tetapi juga aplikasinya dalam ragam materi, institusi, budaya, nilai, dan dampaknya terhadap pemberdayaan umat. Oleh karena, pemahaman tentang seluruh term dimaksud merupakan integrasi holistik dalam mengembangkan sumber daya manusia yang beriman, berislam, dan berihsan. ${ }^{7}$ Jadi sangat wajar kalau para pakar atau praktisi dalam memaparkan definisi pendidikan Islam meninggalkan, dan bahkan sangat concern terhadap konstruksi peserta didik sebagai subjek dan objek, karena memang mereka akan selalu terlibat dalam perbincangan konteks pendidikan Islam.

Mencermati beberapa pengertian yang dipaparkan oleh para pakar pendidikan Islam di atas, dapat dirumuskan bahwa pendidikan Islam ${ }^{8}$ adalah

${ }^{7}$ Sri Minarti, Ilmu Pendidikan Islam: Fakta Teoritis-Filosofis dan Aplikatif-Normatif, Jakarta: Amzah, 2013, Cet.ke-1, h. 26. Lihat juga Abd. Halim Soebahar, Matrik Pendidikan Islam, Yogyakarta: Pustaka Marwa, 2009, h. 12. Ramayulis dan Samsul Nizar mengekspresikan pendidikan Islam merupakan suatu sistem yang memungkinkan peserta didik dapat mengarahkan kehidupannya sesuai dengan ideologi Islam. Melalui pendekatan ini, ia akan dapat dengan mudah membentuk kehidupan dirinya relevan dengan ragam nilai ajaran Islam yang diyakininya. (Ramayulis dan Samsul Nizar, Filsafat Pendidikan Islam: Tela'ah Sistem Pendidikan dan Pemikiran Para Tokohnya, Jakarta: Kalam Mulia, 2009, Cet.ke-3, h. 88). Definisi sedikit berbeda diungkapkan bahwa pendidikan Islam adalah pendidikan yang melatih perasaan peserta didik dengan cara-cara tertentu sehingga dalam sikap hidup, tindakan, keputusan, dan pendekatan terhadap segala jenis pengetahuan sangat dipengaruhi oleh nilai-nilai spiritual dan sadar akan nilai etis Islam. Sementara Muhaimin memfokuskan pada dua dimensi, pertama: aktivitas pendidikan yang diselenggarakan atau didirikan dengan hasrat dan niat untuk mengaktualisasikan ajaran dan nilai-nilai Islam; kedua: pendidikan Islam adalah sistem pendidikan yang dikembangkan dan disemangati oleh nilai-nilai Islam. (Muhaimin, Rekonstruksi Pendidikan Islam: Dari Paradigma Pengembangan, Manajemen Kelembagaan, Kurikulum Hingga Strategi Pembelajaran, Jakarta: Raja Grafindo Persada, 2009, h. 14). Lebih jauh Zakiyah Daradjat dalam Abdul Majid memaparkan bahwa pendidikan Islam merupakan suatu usaha untuk membina dan mengasuh peserta didik agar senantiasa dapat memahami ajaran Islam secara komprehensif. Setelah itu, menghayati tujuan yang pada akhirnya dapat mengamalkan dan menjadikan Islam sebagai pandangan hidup. (Abdul Majid, Pendidikan Agama Islam Berbasis Kompetensi: Konsep dan Implementasi Kurikulum 2004, Bandung: Rosdakarya, 2005, Cet.ke-1, h. 130).

${ }^{8}$ Sistem Pendidikan Islam hendaknya memadukan pendekatan normative deduktif yang bersumber pada system nilai yang mutlak, yaitu al-Qur'an, al-Sunnah, dan Hukum Allah yang terdapat dalam alam semesta dengan pendekatan deskriptif-induktif yang dapat melestarikan aspirasi umat dan peningkatan budaya bangsa sesuai dengan cita-cita kemerdekaan dengan perumusan program pendidikan yang didasarkan kepada konsep variabelitas. Maksudnya adalah suatu proses perumusan tujuan dan penyusunan kurikulum 
proses transinternalisasi pengetahuan dan nilai Islam kepada peserta didik melalui upaya pembelajaran, pembiasaan, bimbingan, pengasuhan, pengawasan, dan pengembangan potensinya, guna mencapai keselarasan dan kesempurnaan hidup di dunia dan akhirat. Pengertian ini memiliki lima dimensi pokok pendidikan Islam, yaitu: Proses Transinternalisasi, Pengetahuan dan Nilai Islam, Kepada Peserta Didik, Melalui upaya Pembelajaran, dan Guna Mencapai Keselarasan dan Kesempurnaan Hidup di Dunia dan Akhirat.

Selanjutnya tujuan pendidikan Islam adalah mewujudkan manusia yang berkepribadian Islam; melatih dan membimbing agar peserta didik menguasai tsaqafah; melatih dan membimbing peserta didik agar dapat menguasai ilmu kehidupan (IPTEK); dan melatih dan membimbing peserta didik agar memiliki ketrampilan yang memadai. ${ }^{9}$

Menurut Hasan Langgulung bahwa tujuan pendidikan agama harus mampu mengakomodasikan tiga fungsi utama dari agama, yaitu fungsi spiritual yang berkaitan dengan akidah dan iman, fungsi psikologis yang berkaitan dengan tingkah laku individual termasuk nilai-nilai akhlak yang mengangkat derajat manusia ke derajat yang lebih sempurna, dan fungsi sosial yang berkaitan dengan aturan-aturan yang menghubungkan manusia dengan manusia lain atau masyarakat. ${ }^{10}$ Term ini menegaskan bahwa tujuan pendidikan Islam berdasarkan pada nilai-nilai Islam itu sendiri. Sementara itu, Ali Yafie menyebutkan bahwa pendidikan agama Islam mempunyai kontribusi yang penting, karena pendidikan agama Islam dapat meningkatkan wawasan keislaman masyarakat, sehingga dapat memahami dan menghayati ajaran agama yang akan mengantarkan kepada pengamalan yang sempurna. ${ }^{11}$

Menela'ah beberapa rumusan tujuan pendidikan Islam di atas, dapat tarik benang merah bahwa tujuan pendidikan Islam memiliki dua sasaran yang ingin dicapai, yaitu pembinaan individu dan pembinaan soaial sebagai sumber khidupan di dunia dan akhirat. Tujuan individu yang ingin

atau silabus yang di dasarkan pada kepentingan lulusan (output oriented) yang bervariasi karena adanya interaksi antara tujuan normative dan deskriptif dengan ragam kepentingan yang berlandaskan kepada adanya perbedaan latar belakang budaya yang meliputi system tata nilai dan norma, system ide dan pola pikir, system pola perilaku, serta system produk budayanya. (Jusuf Amir Feisal, Reorientasi Pendidikan Islam, Jakarta: Gema Insani Press, 1995, Cet.ke-1, h. 116).

${ }^{9}$ M. Saekhan Muchith, Isu-Isu Kontemporer dalam Pendidikan Islam, Kudus: STAIN Kudus, 2009, Cet.ke-1, h. 35-36 . Ekspresi senada ditegaskan bahwa secara umum tujuan pendidikan Islam itu diarahkan pada pembentukan kepribadian yang utama dan akhlakul karimah. Ini relevan dengan misi kerasulan Nabi Muhammad SAW untuk menyempurnakan akhlak mulia berdasarkan pada wahyu Allah, li utammima makarimal akhlak. (Abuddin Nata, Filsafat Pendidikan Islam, Jakarta: Logos Wacana Ilmu, 1997, Cet.ke-1, h. 49

${ }^{10}$ Abuddin Nata, Ibid., h. 46

${ }^{11}$ Ali Yafie, Teologi Sosial, Yogyakarta: LKPSM, 1997, Cet.ke-1, h. 95 
direalisasikan adalah pembentukan pribadi-pribadi muslim yangberakhlak mulia, beriman dan bertakwa dalam rangka mencapai kebahagiaan di dunia dan akhirat. Sedangkan tujuan sosial adalah membangun peradaban manusia yang Islami serta memajukan kehidupan sosial kemasyarakat, sehingga tercipta masyarakat yang berkeadilan, berkemakmuran, dan berkesentosaan relevan dengan motto Negara kita, yaitu adil-makmur-sentosa atau baldatun toyyibatun wa rabbun ghafur.

Sedangkan beberapa sumber pendidikan Islam yang menjadi pedoman pemeluknya, di antaranya adalah:

1. al-Quran al-Karim

2. al-Hadis al-Nabawi

3. Ijma' dan Qiyas (Teori-teori para salafus saleh)

Aneka sumber tersebut di atas, juga menjadi sumber di dalam pendidikan Islam, karena pendidikan merupakan salah satu aspek kehidupan yang menjadi tujuan untuk agama Islam. Dan juga termasuk ke dalam tujuan nabi Muhammad diutus. ${ }^{12}$ Sebagaimana dalam sabdanya: "Sesungguhnya hanyalah aku diutus untuk menyempurnakan akhlak (etika)." (HR. AlBukhari).

Sementara kurikuum pendidikan Islam adalah semua rencana yang terdapat dalam proses pembelajaran. Kurikululm dapat diartikan pula sebagai semua usaha lembaga pendidikan yang direncanakan untuk mencapai tujuan yang disepakati. Sedangkan kurikulum dalam pengertian mutakhir adalah semua kegiatan yang memberikan pengalaman kepada peserta didik di bawah bimbingan dan tanggung jawab sekolah. Kurikulum pendidikan Islam adalah bahan-bahan pendidikan Islam berupa kegiatan, pengetahuan dan pengalaman yang dengan sengaja dan sistematis diberikan kepada peserta didik dalam rangka mencapai tujuan pendidikan Islam. Dengan kata lain kurikulum pendidikan Islam adalah semua aktivitas, pengetahuan dan pengalaman yang dengan sengaja dan secara sistematis diberikan oleh pendidik kepada peserta didik dalam rangka tujuan pendidikan Islam.

Berdasarkan paparan di atas, maka kurikulum pendidikan Islam itu merupakan satu komponen pendidikan agama berupa alat untuk mencapai tujuan. ${ }^{13}$ Artinya, untuk mencapai tujuan pendidikan agama (pendidikan

${ }^{12}$ Omar Mohammad Al-Toumy Al-Syaibany, Op.Cit., h. 247

${ }^{13}$ Tujuan merupakan standar usaha yang dapat ditentukan, serta menagarahkan usaha yang akan dilalui dan merupakan titik pangkal untuk mencapai tujuan-tujuan lain. Di samping itu, tujuan dapat membatasi ruang gerak usaha, agar kegiatan dapat terfokus pada apa yang dicita-citakan, dan yang terpenting lagi adalah tujuan itu dapat memberi penilaian atau evaluasi pada usaha-usaha pendidikan dimaksud. (Ahmad D. Marimba, Pengantar Filsafat Pendidikan, Bandung: al-Ma'arif, 1989, Cet.ke-3, h. 45-46). Perumusan tujuan pendidikan islam harus berorientasi pada hakikat pendidikan yang meliputi bebrapa aspek: tujuan dan tugas hidup manusia; concern terhadap sifat-sifat dasar manusia; tuntutan masyarakat; dan dimensi-dimensi kehidupan ideal Islam. 
Islam) diperlukan adanya kurikulum yang sesuai dengan tujuan pendidikan Islam dan relevan pula dengan tingkat usia, tingkat perkembangan kejiwaan anak dan kemampuan mereka. Sedangkan konten pokok dalam Kurikulum Pendidikan Islam, meliputi:

\section{a. Tujuan}

Tujuan pendidikan agama Islam ini, dapat diklasifikasikan menjadi dua yaitu: tujuan kurikuler dan tujuan pembelajaran. Adapun tujuan kurikuler pendidikan agama Islam adalah untuk meningkatkan keimanan, pemahaman, penghayatan, dan pengalaman peserta didik tentang agama Islam sehingga menjadi manusia muslim yang beriman dan bertakwa kepada Allah SWT. Serta berakhlak mulia dalam kehidupan pribadi, bermasyarakat, berbangsa, dan bernegara.

\section{b. Isi (Konten)}

Isi (Konten)14 kurikulum adalah materi atau bahan pelajaran dan pengetahuan atau pengalaman belajar yang harus diberikan pada peserta didik untuk mencapai materi tersebut.

\section{c. Strategi atau Metode}

Strategi atau metode ${ }^{15}$ adalah pola-pola umum kegiatan pendidik dan peserta didik dalam perwujudan kegiatan belajar mengajar atau kegiatan kurikuler untuk mencapai tujuan yang telah digariskan.

\section{d. Evaluasi}

Evaluasi kurikulum dimaksudkan menilai suatu kurikulum sebagai program pendidikan untuk menentukan efisiensi, efektifitas, relevasi dan produktifitas, program dalam mencapai tujuan pendidikan.

Selanjutnya kurikulum pendidikan Islam meliputi tiga dimensi, yaitu: a. Masalah Keimanan (Aqidah) ${ }^{16}$

${ }^{14}$ Isi (Konten) kurikulum pendidikan Islam mencakup: waktu dan biaya yang tersedia; tekanan internal dan eksternal; persyaratan isi kurikulum dari pusat maupun daerah; tingkat dari isi kurikulum yang akan disajikan. Di sisi lain, isi (konten) kurikulum niscaya memenuhi kriteria pencapaiannya, missal, eksisnya signifikansi, terkait dengan kebutuhan sosial, melihat aspek pragmatisnya, relevan dengan minat dan mengikuti perkembangan manusia, serta melihat struktur disiplin ilmu yang disepakati. (Siswanto, Kurikulum Pendidikan Teknik, Jakarta: Direktorat Jenderal PT-PPLPTK Depdikbud, 1989, Cet.ke-1, h. 24).

${ }^{15}$ Metode adalah cara yang paing tepat dan cepat. Oleh karena itu, metode merupakan ukuran kerja yang harus diperhitungkan secara ilmiah, sehingga metode senantiasa hasil eksperimen yang telah teruji. (Ahmad Tafsir, Metodologi Pengajaran Agama Islam, Bandung: Remaja Rosdakarya, 2004, Cet.ke-4, h. 9).

${ }^{16}$ Dalam bahasa Arab akidah berasal dari kata al-'aqdu (الْعَقُدُ) yang berarti ikatan, at-

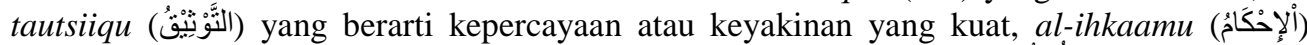

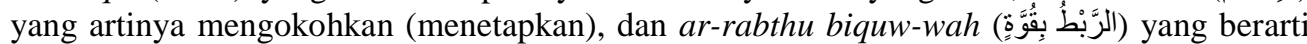
mengikat dengan kuat. Sedangkan menurut istilah (terminologi), akidah adalah iman yang teguh dan pasti, yang tidak ada keraguan sedikit pun bagi orang yang meyakininya. Jadi, Akidah Islamiyyah adalah keimanan yang teguh dan bersifat pasti kepada Allah dengan 
Bagian aqidah menyentuh hal-hal yang bersifat $i$ 'tiqad (kepercayaan). Termasuk mengenai iman setiap manusia dengan Allah, Malaikat, Kitabkitab, Rasul-rasul, Hari Qiamat serta Qada dan Qadar Allah SWT. Masalah keimanan mendapat prioritas pertama dalam penyusunan kurikulum karena pokok ajaran inilah yang pertama perlu ditanamkan pada peserta didik.

\section{b. Masalah Keislaman (syariah) ${ }^{17}$}

Bagian syariah meliputi segala hal yang berkaitan dengan amal perbuatan manusia dalam kehidupan sehari-hari yang berkaitan dengan peraturan hukum Allah dalam mengatur hubungan manusia dengan Allah dan antara sesama manusia. Aspek pergaulan hidup manusia dengan sesamanya sebagai pokok ajaran Islam yang penting ditempatkan pada prioritas kedua dalam urutan kurikulum ini.

\section{c. Masalah Ihsan (akhlak) ${ }^{18}$}

segala pelaksanaan kewajiban, bertauhid dan taat kepadaNya, beriman kepada para malaikatNya, rasul-rasulNya, kitab-kitabNya, hari Akhir, takdir baik dan buruk dan mengimani seluruh apa-apa yang telah shahih tentang prinsip-prinsip Agama (Ushuluddin), perkara-perkara yang ghaib, beriman kepada apa yang menjadi ijma' (konsensus) dari

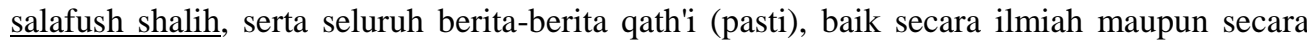
amaliyah yang telah ditetapkan menurut Al-Qur'an dan As-Sunnah yang shahih serta ijma' salaf as-shalih. (Wikipedia.org).

${ }^{17}$ Secara etimologi syariah berarti aturan atau ketetapan yang Allah perintahkan kepada hamba-hamba-Nya, seperti: puasa, shalat, haji, zakat dan seluruh kebajikan. Kata syariat berasal dari kata syar'a al-syai'u yang berarti menerangkan atau menjelaskan sesuatu. Atau berasal dari kata syir'ah dan syariah yang berarti suatu tempat yang dijadikan sarana untuk mengambil air secara langsung sehingga orang yang mengambilnya tidak memerlukan bantuan alat lain. Syariat dalam istilah syar'i hukum-hukum Allah yang disyariatkan kepada hamba-hamba-Nya, baik hukum-hukum dalam Al-Qur'an dan sunnah nabi Saw dari perkataan, perbuatan dan penetapan. Syariat dalam penjelasan Qardhawi adalah hukumhukum Allah yang ditetapkan berdasarkan dalil-dalil Al-Qur'an dan sunnah serta dalil-dalil yang berkaitan dengan keduanya seperti ijma' dan qiyas. Syariat Islam dalam istilah adalah apa-apa yang disyariatkan Allah kepada hamba-hamba-Nya dari keyakinan (aqidah), ibadah, akhlak, muamalah, sistem kehidupan dengan dimensi yang berbeda-beda untuk meraih keselamatan di dunia dan akhirat. (Darma Suryantari, Definisi Syari'ah, 31 Januari 2013, di akses, 10 April 2017).

${ }^{18}$ Akhlak secara terminologi berarti tingkah laku seseorang yang didorong oleh suatu keinginan secara sadar untuk melakukan suatu perbuatan yang baik. Akhlak merupakan bentuk jamak dari kata khuluk, berasal dari bahasa Arab yang berarti perangai, tingkah laku, atau tabiat. cara membedakan akhlak, moral dan etika yaitu Dalam etika, untuk menentukan nilai perbuatan manusia baik atau buruk menggunakan tolok ukur akal pikiran atau rasio, sedangkan dalam moral dan susila menggunakan tolok ukur norma-norma yang tumbuh dan berkembang dan berlangsung dalam masyarakat (adat istiadat), dan dalam akhlaq menggunakan ukuran al-Qur'an dan al-Hadis untuk menentukan baik-buruknya.Tiga pakar di bidang akhlak yaitu Ibnu Miskawaih, Al Gazali, dan Ahmad Amin menyatakan bahwa akhlak adalah perangai yang melekat pada diri seseorang yang dapat memunculkan perbuatan baik tanpa mempertimbangkan pikiran terlebih dahulu. (Wikipedia.org). 
Bagian akhlak merupakan suatu amalan yang bersifat melengkapkan kedua perkara di atas (keimanan dan keislaman) dan mengajar serta mendidik manusia mengenai cara pergaulan dalam kehidupan bermasyarakat.

Mencermati ketiga ajaran pokok tersebut di atas, pada akhirnya diformat menjadi Rukun Iman, Rukun Islam dan Akhlak. Dari ketiga format ini pula, lahirlah beberapa hukum agama, berupa ilmu tauhid, ilmu fiqih dan ilmu akhlak. Selanjutnya ketiga kelompok ilmu agama ini kemudian dilengkapi dengan pembahasan dasar hukum Islam, yaitu al-Quran dan alHadis serta ditambah lagi dengan sejarah Islam. Hal yang perlu diprioritaskan dalam kurikulum pendidikan Islam: Pertama adalah al-Quran dan Hadis; Kedua adalah bidang ilmu yang meliputi kajian tentang manusia sebagai individu dan juga sebagai anggota masyarakat. Menurut terminologi modern sektor ini dikenali sebagai kemanusiaan (al-ulum al-insaniyah). Sektor disiplin ilmu yang terdiri dari psikologi, sosiologi, sejarah, ekonomi dan lainlain; Ketiga adalah bidang ilmu mengenai alam atau sains natural (al-ulum al-kauniyyah), yang meliputi sektor disiplin ilmu, seperti: astronomi, biologi dan lain-lain. Sedangkan terkait dengan sistem pembelajaran dan teknik penyampaian adalah terserah kepada kebijakan pendidik melalui pengalamannya dengan cara memperhatikan bahan yang tersedia, waktu serta jadwal yang sudah ditetapkan oleh pihak tertentu (sekolah masing-masing).

Selain kurikulum, terdapat kajian institusi pendidikan Islam, yang diklasifikasikan pada dua peringkat, yaitu peringkat awal Islam dan peringkat kedua. Peringkat Awal Islam, terdiri dari Dar al-Arqam, Masjid, Suffah, dan Kuttab; Sementara Peringkat Kedua mencakup Manazil Ulama dan Istana, Perpustakaan, Perpustakaan Umum, Perpustakaan Semi Umum, Perpustakaan Khusus, dan Madrasah.

\section{PENDIDIKIAN DI ERA GLOBALISASI}

Dalam konteks ke-Indonesiaan, banyak hal perlu dicermati dalam kerangka Pendidikan Islam di era globalisasi. Islam di Indonesia adalah fakta mayoritas umat. Karena itu, secara konsesional umat Islam Indonesia bertanggung jawab dan memiliki kontribusi besar atas perkembangan dan kemajuan Indonesia dalam semua aspek pembangunan, tak terkecuali dalam bidang pendidikan, secara prioritas pendidikan Islam. Sebab pendidikan Islam adalah pendidikan yang bertujuan untuk membentuk pribadi muslim seutuhnya, mengembangkan seluruh potensi manusia baik yang berbentuk jasmanniah maupun rohaniah, menumbuh suburkan hubungan harmonis setiap pribadi dengan Allah, manusia, dan alam semesta. ${ }^{19}$ Pendidikan itu lebih banyak ditujukan kepada perbaikan sikap mental yang akan terwujud

\footnotetext{
${ }^{19}$ Abdul Majid, Belajar dan Pembelajaran Pendidikan Agama Islam, Bandung: Remaja Rosdakarya, 2012, Cet.ke-3, h. 47
} 
dalam amal perbuatan, baik bagi keperluan diri sendiri maupun orang lain. Pendidikan Islam merupakan proses bimbingan dan pembinaan semaksimal mungkin yang diberikan kepada seseorang melalui ajaran Islam agar orang tersebut tumbuh dan berkembang sesuai tujuan yang diharapkan.20 Pendidikan Islam berarti sistem pendidikan yang memberikan kemampuan seseorang untuk memimpin kehidupannya sesuai dengan cita-cita dan nilainilai Islam yang telah menjiwai dan mewarnai corak kepribadiannya, dengan kata lain pendidikan Islam adalah suatu sistem kependidikannya yang mencakup seluruh aspek kehidupan yang dibutuhkan oleh hamba Allah sebagaimana Islam telah menjadi pedoman bagi seluruh aspek kehidupan manusia baik duniawi maupun ukhrawi.21 Dengan demikian, pendidikan Islam itu berupaya untuk mengembangkan individu sepenuhnya, agar orang tersebut tumbuh dan berkembang sesuai tujuan yang diharapkan yaitu tujuan duniawi maupun ukhrawi.

Karena globalisai merupakan suatu entitas, betapapun kecilnya, yang bila mana disampaikan oleh siapapun, dimana pun, dan kapan pun, akan dengan cepat menyebar keseluruh pelosok dunia, maka entitas tadi telah menjadi lifestyle dan bahkan menjadi simbol kemodernan, ia dapat mengubah kebiasaan hidup seseorang, serta tak jarang menilai ajaran agama sebagai ketinggalan zaman. Jika pendidikan Islam tidak berbuat apa-apa dalam menghadapi perkembangan teknologi canggih di era globalisasi ini, dapat dipastikan bahwa umat Islam akan pasif sebagai penonton, bukan pemain, atau sebagai konsumen, bukan produsen. Maka, upaya memformat ulang teori dan praktik pendidikan Islam, tidak bisa tidak niscaya segera dilakukan, yaitu dengan pembenahan wawasan dan pola pikir: berbuat secara lokal, berfikir secara global. Pendidikan Islam hendaknya dapat kembali kepada sumber "lokalnya" yang autentik, yakni al-Qur'an dan al-Hadist, sambil memperluas wawasan terhadap perkembangan zaman, modernitas, serta mendesain temuan sains dan teknologi sedemikian rupa, hingga pembaharuan

\footnotetext{
${ }^{20}$ Abdullah Idi dan Toto Suharto, Revitalisasi Pendidikan Islam, Yogyakarta: Tiara Wacana, 2006, Cet.ke-1, h. 51

${ }^{21}$ https://aghoestmoemet.wordpress.com/2013/10/11/makalah-ilmu-pendidikan-islam/, diakses pada tanggal 15 April 2017. Kajian historis tentang pendidikan Islam di Indonesia sejak awal masuknya Islam ke Indonesia dapat dibagi kepada tiga fase. Fase pertama, sejak mulai tumbuhnya pendidikan Islam yang diawali masuknya Islam ke Indonesia sampai munculnya zaman pembaharuan pendidikan Islam di Indonesia; fase kedua, sejak masuknya ide-ide pembaharuan pendidikan di Indonesia sampai zaman kemerdekaan; dan fase ketiga, sejak zaman kemerdekaan sampai sekarang, yaitu sejak diberlakukannya undang-undang sistem pendidikan nasional: UU No. 4 Tahun 50 tentang Dasar-Dasar Pempelajaran; UU No. 12 Tahun 1954 tentang Pernyataan Berlakuknya UU No. 4 Tahun 1950; UU No. 2 Tahun 1989 tentang Sistem Pendidikan nasional; dan UU No. 20 Tahun 2003 tentang Sistem Pendidikan Nasional. (Haidar Putra Daulay, Pendidikan Islam dalam Sistem Pendidikan Nasional di Indonesia, Jakarta: Prenada Media Group, 2012, Cet.ke-3, h. 3-4).
} 
pendidikan Islam tidak mulai dari titik start nol. Fakultas Tarbiyah dan Keguruan sebenarnya merupakan aset yang amat berharga dalam melakukan upaya membangun format pendidikan Islam di masa depan. Sebab, ibarat sebuah laboratorium, fakultas ini diarahkan untuk menghasilkan masterpiece dalam hal konsep baru pendidikan Islam. semua tergantung dari apa yang dilakukan sekarang.

\section{SIMPULAN DAN REKOMENDASI \\ Simpulan}

Mencermati bab per bab dari paparan di atas, maka penelitian ini dapat disimpulkan bahwa Substansi Pendidikan Islam di Era Globalisasi merupakan pendidikan rahmatan lil 'alamiin, yang mampu menggagas dan memformat pendidikan Islam sebagai pencetus, penggerak, perubahan, dan pembentukan manusia menjadi makhluk yang memberikan rahmat bagi seluruh alam beserta isnya.

Sementara Pendidikan Islam di Era Globalisasi niscaya dikaji secara Konsepsi dan Aplikasi, karena kebutuhan manusia terhadap pendidikan Islam bersifat mutlak dalam kehidupan pribadi, keluarga, masyarakat, bangsa dan bahkan negara untuk membentuk manusia paripurna yang berakhlak mulia.

Sedangkan Aktualisasi Desain Pendidikan Islam di Era Globalisasi: Antara Konsepsi dan Aplikasi adalah merealisasikan tiga dimensi fital terkait dengan tujuan pendidikan Islam, kurikulum pendidikan Islam dan lembaga pendidikan Islam dalam tataran kehidupan sehari-hari.

\section{Rekomendasi}

Rekomendasi ini diarahkan pada pimpinan institusi pendidikan Islam, para pendidik dan peneliti.

\section{a. Pimpinan Institusi Pendidikan Islam}

Seyogyanya pimpinan institusi pendidikan Islam untuk senantiasa mengakomodir hasil penelitian semacam ini, dan mensupport dalam mengaktualisasikannya terhadap civitas akademika institusi yang dipimpin, sehingga tercipta nuansa akademis-dinamis.

\section{b. Para Pendidik}

Akan lebih dinamis, jika para pendidik mengembangkan hasil penelitian ini, dan mengimplementasikannya dalam proses pembelajaran terhadap peserta didik secara proaktif, dengan memberikan stimulus tertentu untuk meningkatkan produktifitas dan mengeksplorasi inovasi yang mereka miliki, sehingga kondisi pembelajaran semakin hidup. 


\section{c. Peneliti}

Sangat menarik, apabila peneliti dapat mensosialisasikan hasil penelitiannya kepada seluruh pendidik dan yang memang concern terhadap terminologi ini, sehingga hasil penelitian ini bermanfa'at bagi siapa saja yang membutuhkannya.

\section{REFERENSI}

Ainurrafiq. "Pesantren dan Pembaharuan: Arah dan Implikasi". Dalam Abuddin Nata, Sejarah Pertumbuhan dan Perkembangan LembagaLembaga Islam di Indonesia. Jakarta: Gramedia Widiasarana Indonesia. 2001.

Al-Abrasyi, Athiyaah. Ruh Al-Tarbiyah wa Al-Ta'lim. Aleppo: Dar Ihya' alKutub al Arabiyah. 1998.

Al-Faruqi, Ismail Raji. Islamisasi Pengetahuan. diterjemahkan oleh Anas Wahyuddin. Bandung: Pustaka. 1984.

Al-Jabari, Muhammad Abid. Bunyat Aqli al-Arabi. Dirosat Ta'liiliyyat Naqdiyyai Linadhmi al-Ma;rifah fi al Soqofah al-Arrobiyyat. Beirut: Markas al-Wahdah al-Rabiah. 1990.

An Nahlawi, Abdur Rahman. Usulut Tarbiyatul Islamiyati wa asalibiha fil bait wal Mujtama. Mesir: Darul Fikkri. 1998.

Arief, Armai. Sejarah Pertumbuhan dan Perkembangan Lembaga Pendidikan Islam Klasik. Bandung: Angkasa. 2004.

Arif, Mahmud. Pendidikan Islam Transformatif. Yogyakarta: LkiS. 2008.

Dacholfany, M. Ihsan. Reformasi Pendidikan Islam Dalam Menghadapi Era Globalisasi: Sebuah Tantangan dan Harapan. AKADEMIKA. Vol. 20, No. 01 Januari - Juni 2015.

Danim, Sudarman. Agenda Pembaharuan Sistem Pendidikan. Yogyakarta: Pustaka Pelajar. 2003.

Dimyati, M. Keilmuan Pendidikan Sekolah Dasar: Problem Paradigma Teoritis dan Orientasi Praktis Dilematis. Malang: IPTI. 2002.

Esha, Muhammad In'am. Institusional Transformation, Reformasi dan Modernisasi Pendidikan Tinggi Islam. Malang: UIN-Malang Press.

Frire, Paolo. Politik Pendidikan; Kebudayaan, Kekuasaan, dan Pembebasan. Yogyakarta: 2000.

Hamlyn, DW. "History of Epistemology" dalam Paul Edwards, The Encyclopaedia of Philosophy, New York: MacMillan Publishisng Co,Inc, and The Pree Press 1982.

Harre, R. The Philosophies of Science: An Introductory Survey. London: Oxford University Press. 1979.

Hitami, Munzir. IAIN Antara Misi Akademis dan Misi Agama: Telaah atas Perubahan IAIN Menjadi UIN, dalam Potensia; Jurnal Kependidikan 
Islam, Vol. 4, No. 1. Pekanbaru: Fak. Tarbiyah dan Keguruan UIN Suska Riau. 2005.

Jasin, Anwar. "Kerangka Dasar Pembaharuan Pendidikan Islam: Tinjauan Filosofis". AKADEMIKA. Vol. 20, No. 01 Januari - Juni 2015.

Lubis, M. Solly. Umat Islam Dalam Globalisasi. Jakarta: Gema Insani Press. 1997.

Ma'arif, Syamsul. Revitalisasi Pendidikan Islam. Yogyakarta: Graha Ilmu. 2007.

Madjid, Nurcholis. Bilik-bilik Pesantren: Sebuah Potret Perjalanan. Jakarta: Paramadina. 1997.

Mastuhu. Memberdayakan Sistem Pendidikan Islam. Jakarta: Logos Wacana Ilmu. 2002.

Muhaimin. Pengembangan Kurikulum Pendidikan Agama Islam: di Sekolah, Madarasah dan Perguruan Tinggi. Jakarta: Raja Grafindo Persada. 2008.

Mulkhan, Abdul Munir. Paradigma Intelektual Muslim: Pengantar Filsafat Pendidikan Islam dan Dakwah. Yogyakarta: SIPRES. 1993.

Qodri, Azizy. Melawan Globalisasi, Reinterpretasi Ajaran Islam. Yogyakarta: Pustaka Pelajar. 2003.

Saefuddin, A.M. dkk. "Konsep Pendidikan Agama: Sebuah Pendidikan Integratif-inovatif", dalam A.M. Saefuddin et.al., Desekularisasi Pemikiran: Landasan Islamisasi. Bandung: Mizan. 1991.

Salim, Agus. Perubahan Sosial: Sketsa Teori dan Refleksi Metodologi Kasus Indonesia. Yogyakarta: PT Tiara Wacana, 2002.

Soroyo. Antisipasi Pendidikan Islam dan Perubahan Sosial. Yogyakarta: Tiara Wacana. 2000.

Subagja, Soleh. Gagasan Libralisasi Pendidikan Islam: Konsepsi Pembebasan dalam Pendidikan Islam. Malang: Madani. 2010.

Sugiharto, Bambang. Humanisme dan Humanoria Relevansinya Bagi Pendidikan. Yogyakarta: Jalasutra. 2008.

Sutrisno. Pembaharuan Dan Pengembangan Pendidikan Islam. Yogyakarta: Fadilatama, 2011.

Tafsir, Ahmad. Ilmu Pendidikan Islam dalam Perspektif Islam. Bandung: Remaja Rosda Karya. 2000.

Umar Muhammad At-Taumi \& As Shaybani. Falsafah Pendidikan Islam, Terjemahan. Hasan Langgulung. Jakarta: Bulan Bintang. 1995.

Usa, Muslih Usa (ed). Pendidikan Islam di Indonesia antara Cita dan Fakta. Yogyakarta: PT Tiara Wacana. 1991.

Zada, Khamami. "Orientasi Studi Islam di Indonesia Mengenal Pendidikan Kelas Internasional di Lingkungan PTAI”. Istiqro: Jurnal Penelitian Direktorat Perguruan Tinggi Agama Islam, Dirjen Kelembagaan 
Agama Islam Departemen Agama RI, Vol, VI/No. O2/2003. Jakarta: Departemen Agama Republik Indonesia. 2003.

Zaini, Syahminan. Prinsip-prinsip Dasar Konsepsi Pendidikan Islam. Jakarta: Kalam Mulia. 1986.

Zuhairini. Filsafat Pendidikan Islam. Jakarta: Bumi Aksara. 1995. 